\title{
Politicizing the Mask: Political, Economic and Demographic Factors Affecting Mask Wearing Behavior in the USA
}

\author{
Leo H. Kahane ${ }^{1}$
}

Published online: 5 January 2021

(c) EEA 2021

\begin{abstract}
This paper uses survey data at the county level to explore the factors determining mask-wearing behavior in the USA during the COVID-19 pandemic. Empirical results provide evidence that the tendency to wear a mask while in public is significantly lower in counties where then-candidate Donald Trump found strong support during the 2016 presidential election. In addition, states with mask-wearing mandates tend to witness greater mask-wearing behavior.
\end{abstract}

Keywords Facemask wearing · Corona virus · COVID-19 $\cdot$ Donald Trump $\cdot$ Mask mandates

JEL Classification D72 $\cdot$ I12 $\cdot$ I18

\section{Introduction}

In the spring of 1918 the Great Influenza Pandemic, commonly referred to as the 'Spanish Flu,' had made its way to the shores of the USA. ${ }^{1}$ While statistics related to the pandemic are scarce, the Centers for Disease Control and Prevention (CDC) reports that an estimated 500 million people, or about one-third of the world population became infected. The total number of deaths is estimated to be 50 million. For

\footnotetext{
1 Barro et al. (2020, p. 2, fn. 1) notes that there is little evidence to suggest that the onset of the Great Influenza Pandemic can be traced to Spain. They note that at the time Spain, due to its neutral status in World War I, had a freer press and as such provided much greater news coverage of the disease leading it to be known as the 'Spanish Flu.'
}

Leo H. Kahane

lkahane@providence.edu

1 Michael A. Ruane Distinguished Chair in Economics, Department of Economics, Providence College, 1 Cunningham Square, Providence, RI 02918, USA 
the USA, the estimated number of deaths is 675 thousand. ${ }^{2}$ Shortly after the flu was identified in March of 1918 at an Army base in Kansas medical authorities urged the use of face masks to fight against the spread of the virus. San Francisco was the first US city to implement a mask-wearing ordinance, signed into law by Mayor James Rolph on October 22, 1918. Various other cities followed San Francisco's example with their own mask-wearing laws. While compliance was the norm, there was opposition as some saw the ordinances as a "symbol of government overreach." 3 This opposition to mandated mask wearing crystalized in 1919 with the formation of the 'Anti-Mask League' in San Francisco, which led protests against mask wearing. Dolan (2020) writes that the Anti-Mask League protests, "might be cloaking deeper ideological or political divides." In other words, opposition to mask wearing during the Great Influenza Pandemic may have reflected both a disbelief by some that masks were effective in reducing the spread of the deadly virus, as well as an example of government's infringement on one's personal liberty.

Fast-forward approximately 102 years and we find ourselves in the middle of another pandemic, the Novel Coronavirus Disease, or COVID-19. Data now are much more reliable and accessible in comparison with the Great Influenza Pandemic. On March 11, 2020 the World Health Organization (WHO) declared COVID-19 as being a global pandemic. ${ }^{4}$ The WHO reports that as of August 16, 2020 the cumulative number of confirmed COVID-19 cases is estimated to be 21.2 million with 760 thousand deaths worldwide. ${ }^{5}$ The CDC reports that for the USA, total cases come to over 5.46 million with deaths totaling just over 171 thousand as of August 19, 2020. ${ }^{6,7}$ As with the case of the Great Influenza Pandemic, health officials are urging all people to wear facemasks when they are in public and within six feet of another person. The efficacy of facemask wearing is not in dispute as research has shown that facemasks are effective in reducing the spread of the virus. ${ }^{8}$ Yet, as it was in 1918, there is opposition to face mask mandates as protestors in places like Provo, Utah and Tulsa, Oklahoma gathered to oppose such mandates. These protestors have found an ally in US President Donald Trump who has ignored

\footnotetext{
2 "History of 1918 Flu Pandemic," Centers for Disease Control and Prevention, https://www.cdc.gov/flu/ pandemic-resources/1918-commemoration/1918-pandemic-history.htm, accessed on August 20, 2020. The one-third infection rate is in agreement with Frost (1920).

3 Hauser (2020).

4 "New ICD-10-CM code for the 2019 Novel Coronavirus (COVID-19)," Centers for Disease Control and Prevention, https://www.cdc.gov/nchs/data/icd/Announcement-New-ICD-code-for-coronavirus-3-182020.pdf?fbclid=IwAR1W4E21-xZbEJdSG-RFewVZmuM72GGhiE2QIRyur_CPStp14uAa8gzhRXw, accessed on August 20, 2020.

5 "Coronavirus disease (COVID-19) Weekly Epidemiological Update 1," World Health Organization, https://www.who.int/docs/default-source/coronaviruse/situation-reports/20200817-weekly-epi-update-1. pdf?sfvrsn=b6d49a76_4, accessed on August 20, 2020.

6 "Coronavirus Disease 2019 (COVID-19): Cases in the U.S." https://www.cdc.gov/coronavirus/2019ncov/cases-updates/cases-in-us.html, updated on August 19, 2020.

7 At the time of revising this draft, the numbers now stand at more than 14.6 million total cases and over 281 thousand deaths in the USA, CDC COVID Data Tracker, https://covid.cdc.gov/covid-data-track er/\#cases_casesper100klast7days, accessed on December 8, 2020.

8 See, for example, MacIntyre and Chughtai (2020) and Zhang et al. (2020).
} 
the CDC's urging of the use of facemasks. President Trump has politicized the issue as he noted on April 3, 2020 that the CDC recommendations are voluntary and stating, "You don't have to do it. They suggested for a period of time, but this is voluntary. I don't think I'm going to be doing it." ${ }^{9}$ Later, during a September 29 debate with Joe Biden, Trump chided Biden for wearing a mask, noting, "Every time you see him, he's got a mask. He could be speaking 200 feet away from them, and he shows up with the biggest mask I've ever seen." ${ }^{10}$ Further, given the Trump administration's reluctance to put forward a national mask-wearing mandate, a collection of individual states have implemented laws requiring facemasks. As of August 17, 2020, thirty-four states and Washington D.C. have mask mandates. Of the sixteen states that do not have a facemask mandate, all have a governor who is a member of the Republican Party.

There is evidence of a general, growing partisan divide between Democrats and Republicans in the US over the last 4 decades (Boxell et al. 2020). Further, survey results by the Pew Research Center (2017) show that the growth in this division has accelerated under Donald Trump's presidency. Bordalo et al. (2020) notes that when the division between Democrats and Republicans grows this typically leads to greater political engagement (e.g., voting, participation in political campaigns, political contributions). Such polarization and increased partisan awareness would seem to create conditions where the views and the behavior of the president could have strong influences on those who support him. In this light, considering President Trump's reluctance to impose a nation-wide requirement for wearing masks while in public, and his own unwillingness to personally wear a facemask, a question arises: has President Trump's views and behavior regarding masks had an impact on the mask-wearing behavior of those who support him? The goal of this paper is to explore this potential linkage empirically. Using county-level survey data, collected by the firm Dynata at the request of the New York Times, econometric results show a significant, negative relationship between mask-wearing behavior and county-level voting for Donald Trump in the 2016 presidential election. Understanding this linkage is important as it highlights how partisan divisions and powerful influences by political leaders may lead to suboptimal decisions by individuals that are costly both economically and in terms of public health.

The remainder of this paper is organized as follows. The next section provides some discussion of related literature. Section three follows with the empirical model employed and a description of the data used to test it. Section four contains the estimations results. Section five contains some concluding thoughts.

\footnotetext{
9 "In His Own Words, Trump on the Coronavirus and Masks," New York Times, October 2, 2020. Accessed online at: https://www.nytimes.com/2020/10/02/us/politics/donald-trump-masks.html.

10 Same reference as footnote 9 .
} 


\section{Related Literature}

Although the COVID-19 pandemic is relatively new, there is a sizeable body of economic research on the topic. ${ }^{11}$ Much of the research by economists has involved attempts to quantify the pandemic's effects on the number of deaths, income, employment and mortality rates. ${ }^{12}$ Research focusing on the political economy of the pandemic and health care policy is slowly emerging.

A paper by Purtle et al. (2017) pre-dates the COVID-19 pandemic and focuses on the more general question of whether there is a partisan impact on the formation of healthcare policy. The authors examine voting patterns of US Senators on healthcare legislation over the years from 1998 to 2013 (a total of 1434 votes on 111 bills). They compute the proportion of the time that Senators voted in favor of policies deemed to be in the interest of public health according to the non-partisan American Public Health Association (APHA). After controlling for various factors (e.g., Senator gender, and regional and voting year effects), the authors find that Democrats voted in concordance with the APHA recommendations about 59 percent more often than Republicans.

Regarding research more directly related to the present paper, three recent papers have emerged that consider the partisan effects on social distancing behavior and compliance during the coronavirus pandemic. The paper by Alcottt et al. (2020) begins by emphasizing the partisan differences between Democrats and Republicans (as well as media outlets) on the severity of the COVID-19 pandemic and the importance of social distancing in combatting the virus. They then employ GPS location data on smartphones to account for individuals' daily and weekly point of interest visits (e.g., restaurants, hotels, hospitals, etc.) where social distancing would be difficult. The authors show that, other things equal, Republicans were less likely to socially distance while in public than were Democrats.

In a similar approach, Painter and Qiu (2020) use geolocation data from smartphones and data on debit card transactions to assess the effectiveness of state-level social distancing policies. The authors' measure of social distancing is the percentage of a county's population that remained at home for the entire day. After controlling for various county-level demographics and voting behavior in the 2016 presidential election, they find (among other things) that Republican counties respond less to state-mandates for social distancing than Democratic counties.

Clinton et al. (2020) utilize survey data from nearly 650 thousand individuals obtained from March 4 to July 2, 2020. The authors examine the self-reported social distancing behavior of surveyees over the last 24 hours. Controlling for various individual-level and zip code-level demographics, the presence of COVID-19 in the community, and including state fixed effects the authors find that individuals who identified as Republicans were less likely to engage in social distancing. Further, the authors note that this partisanship effect appears to be growing over time.

\footnotetext{
11 A simple search for 'COVID-19' of the National Bureau of Economic Research (NBER) working papers will yield over 100 results, (see: https://www.nber.org/papers/).

12 Examples include Barro et al. (2020); Chetty et al. (2020); Goldstein and Lee (2020).
} 
A common element contained in the last three papers described above is a finding that political divisions appear to be affecting the behavior of individuals regarding their response to the COVID-19 pandemic. The present paper continues along this line of research, but with a focus not on social distancing behavior but on another behavior seen to be key to reducing the spread of COVID-19-the practice of wearing a facemask. This method of preventing the spread of the virus is somewhat different from social distancing in that the wearing of a facemask is largely for the protection of others, not the individual, while in public. The empirical model employed is described in the next section.

\section{Model and Data Description}

In order to explore the factors affecting mask-wearing behavior in the USA, this paper makes use of a data set assembled by the survey firm, Dynata. ${ }^{13}$ At the request of the New York Times, Dynata surveyed 250,000 US respondents between July 2 and July 14, 2020. ${ }^{14}$ The survey asked each participant the following question: "How often do you wear a mask in public when you expect to be within six feet of another person?" Responses included, "always," "frequently," "sometimes," "rarely," and "never." These responses were aggregated to the county level to create the percentage of respondents that answered in each of these five responses.

In order to create a dependent variable for use in the econometric analysis a "mask index' was constructed in the following way. A response of "always" was assigned a value of 4, "frequently" was assigned a value of 3, "sometimes" was assigned a value of 2, "rarely" was assigned a value of 1 , and "never" was assigned a value of 0 . Using these assigned values and the associated percentage responses to the survey question, the following equation is used to construct a weighted sum, county-level index of mask-wearing behavior:

$$
\text { mask index }_{i}=\left(\alpha_{0, i} * 0\right)+\left(\alpha_{1, i} * 1\right)+\left(\alpha_{2, i} * 2\right)+\left(\alpha_{3, i} * 3\right)+\left(\alpha_{4, i} * 4\right)
$$

where $\alpha_{0, i}, \alpha_{1, i} \ldots \alpha_{4, i}$ represent the percentage of respondents in county $i$ that responded "never," "rarely,"..."always" to the survey question. Thus, maskindex $_{i}$ can range from 0 to 4 , with increasing values indicating a greater propensity for individuals to wear masks in public when six feet of social distance is not possible. In order to visualize the variation of mask-wearing behavior across the country, Figure 1 shows a count-level heatmap using the index provided in Eq. (1). As can be seen in the heatmap, mask-wearing behavior varies greatly across the country. Regionally, it is clear that masks are commonly worn in public in the West, North

\footnotetext{
13 Their website can be found at: https://www.dynata.com/.

14 Details about how the survey was conducted can be found at: https://github.com/nytimes/covid-19data/tree/master/mask-use. A brief description of the survey methodology can be found in Appendix B.
} 
West, Mid-Atlantic and North East areas. At the same time, mask wearing in public in the Mid-West appears to be much less common. ${ }^{15}$

In order to explore mask-wearing behavior in the U.S. the model shown in Eq. (2) is employed:

$$
\begin{aligned}
\text { mask index }_{i}= & \beta_{o}+\beta_{1} \text { \%votefor } \text { Trump }_{i}+\beta_{2} \text { metro }_{i} \\
& +\beta_{3} \text { nonmetro adj }_{i}+\beta_{4} \text { unemployment }_{i}+\beta_{5} \text { income }_{i} \\
& +\boldsymbol{\beta}_{6} \boldsymbol{D}_{\boldsymbol{i}}+\boldsymbol{\beta}_{7} \boldsymbol{R}_{\boldsymbol{i}}+\boldsymbol{\beta}_{8} \boldsymbol{E}_{\boldsymbol{i}}+\beta_{9} V_{i}+\beta_{10} \text { mask law }_{i}+u_{i}
\end{aligned}
$$

The variable \%votefor Trump $p_{i}$ is the percentage of the popular vote in county $i$ that went for Donald Trump in the 2016 presidential election. The expected sign for $\beta_{1}$ would be negative if the claim that President Trump's own reluctance to wearing a mask in public has contributed to the politicization of mask wearing generally and has led to reduced mask wearing by voters who supported him in the 2016 election. Figure 2 provides a heatmap of voting behavior in the 2016 election. The figure shows strong support for Hillary Clinton in the West, North West, Mid-Atlantic and North East areas and strong support for Donald Trump in the Mid-West, the central part of the South West and considerable support from the South East. A visual comparison of the two heatmaps appears to show some matching between mask-wearing behavior of Fig. 1 and the voting patterns in the 2016 election in Fig. 2.

A variety of control variables are included in Eq. (2). The variables metro ${ }_{i}$ and nonmetro $\operatorname{adj}_{i}$ are two dummy variables which are derived from the US Department of Agriculture's Rural-Urban Continuum Codes which classify counties based on their population and density. The variable metro $_{i}$ takes a value of 1 if the county is classified as a 'metropolitan area' (with a population of 250,000 or more), zero otherwise. The variable nonmetro $a d j_{i}$ takes a value of 1 if the county is not categorized as 'metropolitan' but is adjacent to one, and zero otherwise. The base category thus becomes 'nonmetropolitan, nonadjacent.' It is assumed that, all else equal, individuals living in large metropolitan counties, or in a county adjacent to one, will be more likely to come in close contact with people while in public and as such will be more likely to wear a mask in comparison with people living in more rural, less densely populated areas. Thus, a positive sign is expected for both coefficients to these dummy variables.

The next two measures are included to control for differences in the economic conditions across counties. The variable unemployment $t_{i}$ is the county-level unemployment rate (as of June 2020) in percent. The measure income $_{i}$ is the median household income (in thousands of dollars) for county $i$. There is no firm a priori expectation regarding the signs for these two coefficients. It may be the case that both variables reflect measures of opportunity costs associated with becoming

\footnotetext{
15 It should be noted that the Dynata survey results, like many other surveys, may be subject to 'social desirability bias.' This occurs when individuals respond to survey questions in a way that they believe is socially desirable rather than giving a response that truly matches their feelings. See, for example, King and Bruner (200) for a discussion of this issue. Given that the Dynata survey was conducted online with anonymity of the respondent, problems with social desirability bias are likely to be small.
} 


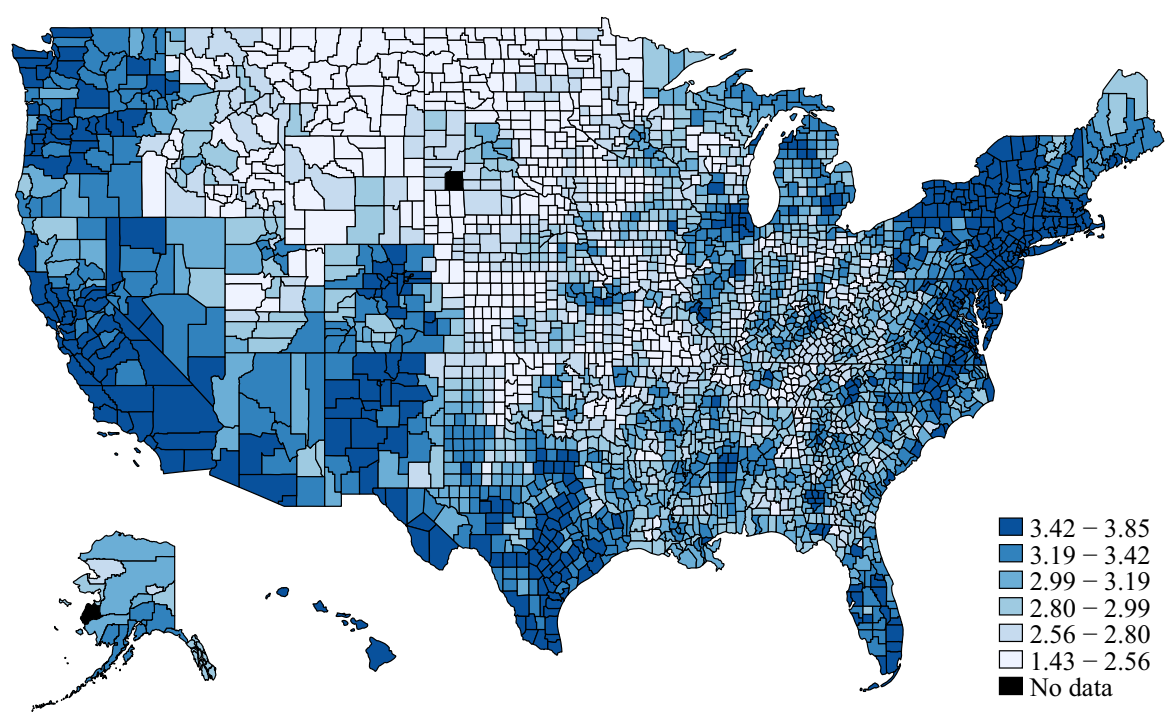

Fig. 1 County-level mask wearing behavior survey question: how often do you wear a mask in public when you expect to be within six feet of another person? $(0=$ 'Never'; 1 = 'Rarely'; 2 = 'Sometimes'; 3 $=$ 'Frequently'; 4 = 'Always')

infected with COVID-19. If this is the case, then we may expect a negative sign for unemployment $_{i}$ and a positive sign for income $_{i} \cdot{ }^{16}$

The vector $\boldsymbol{D}_{\boldsymbol{i}}$ includes various demographic measures for counties. These include measures for gender, race, ethnicity and age groups. As with the economic measures, there are no clear expectations for the signs of these coefficients. However, given long-standing inequities in terms of access to healthcare for minority race and ethnic populations, it may be the case that mask-wearing behavior may be greater among these groups. ${ }^{17}$ Regarding the measures for age groups, the base case is for those aged less than 15. To the extent that COVID-19 is more dangerous for older individuals, ${ }^{18}$ then we should expect positive signs for these age group coefficients.

The vector $\boldsymbol{R}_{\boldsymbol{i}}$ contains three variables measuring county-level risk factors that, according to the CDC, put individuals at greater risk of "severe illness" from COVID-19. ${ }^{19}$ These include hospitalizations of individuals 65 years and older for

\footnotetext{
16 An alternative hypothesis (suggested by an anonymous referee) is that those with greater incomes may typically have better health insurance and as such could better deal with sickness due to COVID-19.

17 See, for example, "Disparities in Incidence of COVID-19 Among Underrepresented Racial/Ethnic Groups in Counties Identified as Hotspots During June 5-18, 2020-22 States, February-June 2020," Centers for Disease Control and Prevention, https://www.cdc.gov/mmwr/volumes/69/wr/mm6933e1.htm, accessed on November 16, 2020.

18 Centers for Disease Control and Prevention, https://www.cdc.gov/coronavirus/2019-ncov/need-extra -precautions/older-adults.html, accessed August 23, 2020.

19 Centers for Disease Control and Prevention, https://www.cdc.gov/coronavirus/2019-ncov/need-extra -precautions/people-with-medical-conditions.html, accessed August 27, 2020.
} 


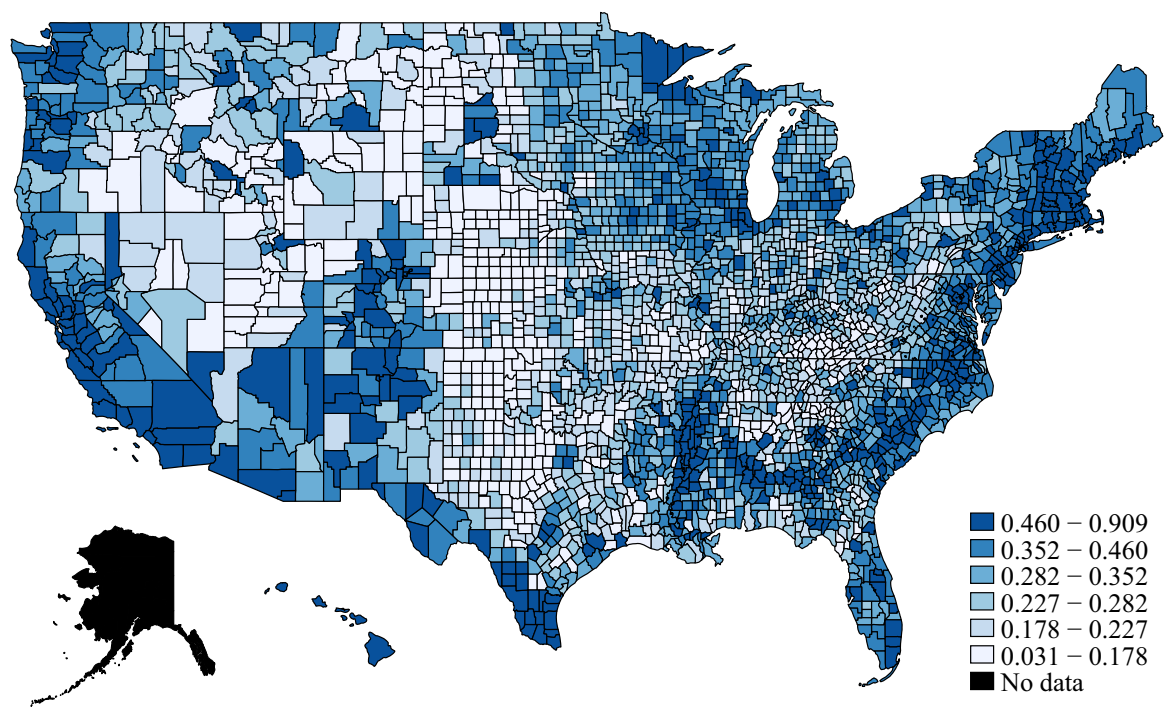

Fig. 2 County voting patterns during the 2016 presidential election (percent of votes cast for Democrat Hilary Clinton)

cardiovascular disease per 1000 beneficiaries (cardio hospitalizations), the percent of the population diagnosed with diabetes (\% diabetes), and the percent of the population that is obese (\% obese). The expected signs for the coefficients for these three variable are positive, implying that in counties where there are more people at greater risk of severe illness due to COVID-19 there will be greater mask-wearing behavior.

The vector $\boldsymbol{E}_{\boldsymbol{i}}$ is comprised of three educational attainment measures. These include the percent of the population that has less than a high school diploma, some college, or a Bachelor's degree or higher, (the base category being the percent of the population with a high school diploma or equivalent). These are included as control variables with no obvious, a priori expectation for the signs of these coefficients.

The variable $V_{i}$ is a measure of how severe the COVID-19 virus is for a county, measured one month prior to when the survey was done for the dependent variable. Two measures are employed. The first is the case fatality ratio, equal to the number of deaths attributed to COVID-19 divided by the number of confirmed cases of COVID-19 for the given period. The second is the case rate, defined as the number of confirmed COVID-19 cases per one thousand population. Both these variables are included to capture the 'scare factor' that the virus brings to the county. It is expected that, all else equal, the larger the value of either measure, the more likely 
people would be willing to wear facemasks to reduce the spread of the virus. ${ }^{20}$ As such, $\beta_{9}$ is expected to be positive. ${ }^{21}$

Lastly, the measure mask $l a w_{i}$ is a dummy variable that takes the value of 1 if there was a state-wide mask law in place prior to the survey, 0 otherwise. To the extent that such laws are enforced, it would likely mean that more people would be wearing masks while in public, all else equal. As such, a positive sign is expected for coefficient $\beta_{10}$.

Table 1 contains summary statistics for the measures entering Eq. (2). There are a total of 3,143 counties and county-equivalents in the USA, including Washington D.C. ${ }^{22}$ Due to missing data on voting (Alaska did not report their 2016 election results by borough), missing data on health measures and missing data created when the case fatality ratio was computed (as the denominator was zero for some counties), the resulting sample size used in Table 1 and in the regressions to follow came to 2,969 . This figure covers approximately 93 percent of all counties.

\section{Estimation Results}

As a simple, first look at the relationship between mask-wearing behavior and support for Donald Trump in the 2016 presidential election, Fig. 3 contains a scatter plot with the mask index for counties on the vertical axis and the percent of total county vote for Trump on horizontal axis. Also included is a least squares regression line for the two measures. As is evident, there is an apparent inverse relationship depicted in the graph. The graph also appears to display the presence of heteroskedasticity.

\section{Main Results}

While Fig. 3 is suggestive, a more careful analysis is called for in order to eliminate the effects of other potentially confounding factors. To that end, Eq. (2) is estimated using several methodologies. In order to simplify the interpretation of the results, the dependent variable, mask index $x_{i}$, has been standardized to mean zero with a standard deviation of one. Thus, the marginal effects represent the expected impact on mask index ${ }_{i}$ in terms of standard deviations from a unit change in the independent variables.

The first regression is a least squares estimation with robust standard errors that are clustered at the state level. Results appear in Table 2, column (1). The model

\footnotetext{
20 The timing of the survey by Dynata may also account for differences in mask-wearing behavior. In states where the virus was very deadly early on (e.g., New York and California), mask wearing behavior may have been more prevalent as the importance of such precautions became evident.

21 There is the possibility of bi-directional causality regarding these measures, particularly for the case rate. The case fatality ratio would seem to be of less concern since the measure considers the likelihood of death from COVID-19, given one is infected.

22 Alaska has 'boroughs' instead of counties; Louisiana has 'parishes.'
} 
Table 1 Summary statistics $(N$ $=2969$ )

\begin{tabular}{|c|c|c|c|c|}
\hline Variable & Mean & $\mathrm{SD}$ & Min & Max \\
\hline mask index & 2.995 & 0.407 & 1.433 & 3.849 \\
\hline$\%$ vote for Trump & 62.559 & 15.575 & 4.087 & 94.585 \\
\hline metro & 0.389 & 0.488 & 0 & 1 \\
\hline non-metro adj & 0.335 & 0.472 & 0 & 1 \\
\hline unemployment rate & 10.504 & 4.030 & 1.6 & 34 \\
\hline income $(\$ 1000 s)$ & 52.887 & 14.011 & 25.385 & 140.382 \\
\hline$\%$ pop. male & 50.042 & 2.205 & 42.992 & 73.486 \\
\hline$\%$ pop. white & 84.375 & 15.940 & 8.028 & 99.035 \\
\hline$\%$ pop. black & 9.795 & 14.684 & 0.081 & 86.593 \\
\hline$\%$ pop. hispanic & 9.788 & 13.836 & 0.648 & 96.353 \\
\hline$\%$ pop. 15 to 29 & 18.627 & 3.864 & 6.834 & 50 \\
\hline$\%$ pop. 30 to 44 & 17.493 & 2.176 & 9.018 & 30.061 \\
\hline$\%$ pop. 45 to 59 & 19.141 & 1.847 & 7.417 & 26.782 \\
\hline$\%$ pop. 60 or more & 26.595 & 5.606 & 7.087 & 66.627 \\
\hline case fatality ratio & 0.034 & 0.050 & 0 & 0.812 \\
\hline cases per 1000 population & 3.748 & 6.608 & 0.02618 & 124.901 \\
\hline cardio hospitalizations & 60.627 & 16.564 & 18 & 133.5 \\
\hline$\%$ diabetes & 10.489 & 3.770 & 1.5 & 33 \\
\hline$\%$ obese & 32.881 & 5.665 & 12.3 & 57.9 \\
\hline$\%$ less than high school & 13.534 & 6.237 & 1.2 & 48.5 \\
\hline$\%$ some college & 30.556 & 5.083 & 11.4 & 48 \\
\hline$\%$ Bachelors or more & 21.629 & 9.549 & 5.4 & 78.5 \\
\hline mask law & 0.463 & 0.499 & 0 & 1 \\
\hline
\end{tabular}

The sample size reflects the number of complete observations used in the regression analysis. Data sources are listed in Appendix 1.

performs well overall with an $R$-squared of 0.619 . Of the variables that are statistically significant, all with an a priori expectation have the predicted signs with the exception of unemployment. The estimated coefficients for the two dummy variables, metro and nonmetro adj, are positive and significant at the one percent level, suggesting that counties that are larger and more densely populated tend to exhibit greater mask-wearing behavior on the order of 0.479 and 0.288 standard deviations, respectively, compared to the base case (nonmetropolitan, nonadjacent counties). Turning to the economic measures, income has a positive coefficient and its magnitude suggests that a one-thousand dollar increase in median household income leads to a 0.008 standard deviation increase in the mask index. This is supportive of the hypothesis noted earlier that counties where incomes are higher may exhibit greater mask-wearing behavior in order to avoid the opportunity cost of contracting the virus. For the variable unemployment, the estimated coefficient is also positive, implying that in counties with greater unemployment rates the mask-wearing behavior is greater-contrary to what was hypothesized. One possible explanation is that states that closed more businesses due to COVID-19 would tend to have higher 


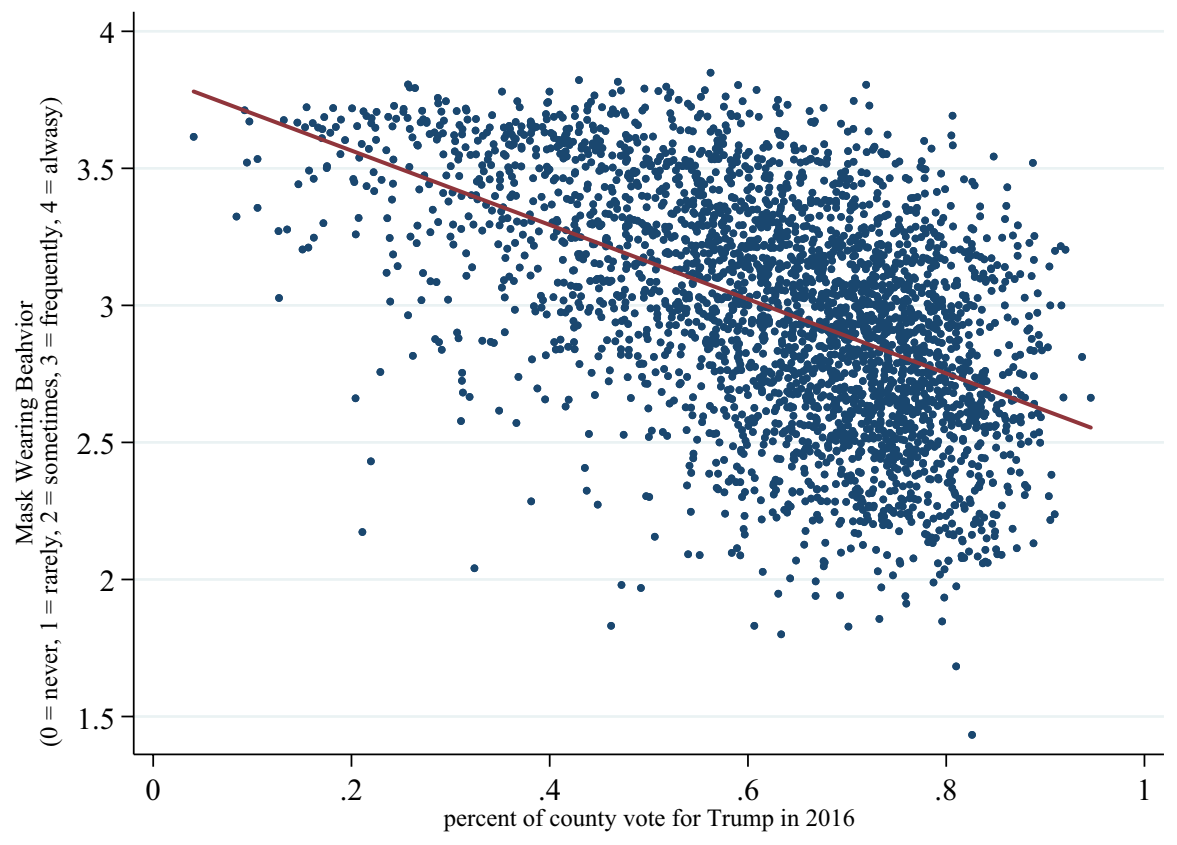

Fig. 3 Scatter plot of mask-wearing behavior and voting in the 2016 election (least-squares regression line included)

unemployment rates. Assuming that many of those who lost their jobs have less access to healthcare, they may take greater precautions by wearing facemasks while in public. ${ }^{23}$

Regarding the controls for race, ethnicity and gender, there were no strong priors on what the expected signs should be. The only variable that is statistically significant in this group is the percent of the population that is Hispanic. The estimated coefficient suggests that a one-percentage point increase in the Hispanic population leads to an approximate 0.02 standard deviation increase in mask-wearing behavior. As noted earlier, this may be a consequence of limited access to health insurance and, hence, being more careful while in public.

As for the age group measures, as predicted, these coefficients indicate that older age groups tend to wear masks more often in comparison with the base case of those aged less than 15 years old. The estimated coefficients suggest that a one-percentage point increase in these age groups leads to an increase in mask-wearing behavior on the order of 0.061 to 0.112 standard deviations, other things equal.

Moving to the case fatality ratio, the estimated sign is positive as expected, yet does not meet the threshold for statistical significance. As for the variables reflecting the presence of high-risk factors in a county, only the measure capturing the prevalence of diabetes in the county is significant. The coefficient to \% diabetes suggests

23 Thanks to an anonymous referee for suggesting this explanation. 
Table 2 OLS and quantile regression results (dependent variable: standardized mask index $_{i}$ )

\begin{tabular}{|c|c|c|c|c|c|c|}
\hline \multirow[t]{2}{*}{ Variables } & (1) & (2) & (3) & (4) & $(5)$ & (6) \\
\hline & OLS & q10 & $\mathrm{q} 25$ & q50 & $\mathrm{q} 75$ & q90 \\
\hline \multirow[t]{2}{*}{$\%$ vote for Trump } & $-0.0107 * * *$ & $-0.00882^{* * * *}$ & $-0.00853 * * *$ & $-0.00973 * * *$ & $-0.0108 * * *$ & $-0.0147 * * *$ \\
\hline & $(0.00304)$ & $(0.00256)$ & $(0.00197)$ & $(0.00153)$ & $(0.00167)$ & $(0.00197)$ \\
\hline \multirow[t]{2}{*}{ metro } & $0.479 * * *$ & $0.586^{* * * *}$ & $0.605^{* * *}$ & $0.492 * * *$ & $0.416^{* * *}$ & $0.290 * * *$ \\
\hline & $(0.0810)$ & $(0.0681)$ & $(0.0554)$ & $(0.0500)$ & $(0.0478)$ & $(0.0586)$ \\
\hline \multirow[t]{2}{*}{ non-metro adj } & $0.288 * * *$ & $0.308^{* * * *}$ & $0.344 * * *$ & $0.295^{* * *}$ & $0.275^{* * *}$ & $0.204 * * *$ \\
\hline & $(0.0649)$ & $(0.0625)$ & $(0.0496)$ & $(0.0449)$ & $(0.0416)$ & $(0.0539)$ \\
\hline \multirow[t]{2}{*}{ unemployment } & $0.0186^{* *}$ & $0.0278 * * *$ & $0.0247 * * *$ & $0.0156 * * *$ & $0.00767 *$ & 0.00402 \\
\hline & $(0.00707)$ & $(0.00551)$ & $(0.00488)$ & $(0.00424)$ & $(0.00402)$ & $(0.00562)$ \\
\hline \multirow[t]{2}{*}{ income } & $0.00822 * *$ & $0.00974 * * *$ & $0.00793 * * *$ & $0.00707 * * *$ & $0.00759 * * *$ & $0.00697 * *$ \\
\hline & $(0.00341)$ & $(0.00318)$ & $(0.00228)$ & $(0.00229)$ & $(0.00238)$ & $(0.00285)$ \\
\hline \multirow[t]{2}{*}{$\%$ pop. male } & -0.0142 & $-0.0351 * * *$ & $-0.0317^{* *}$ & -0.0175 & -0.00275 & 0.00160 \\
\hline & $(0.0127)$ & $(0.0128)$ & $(0.0132)$ & $(0.0114)$ & $(0.0114)$ & $(0.0100)$ \\
\hline \multirow[t]{2}{*}{$\%$ pop. white } & -0.00530 & 0.000500 & 0.00251 & -0.00535 & $-0.00994 * * *$ & -0.00396 \\
\hline & $(0.00396)$ & $(0.00312)$ & $(0.00327)$ & $(0.00340)$ & $(0.00322)$ & $(0.00265)$ \\
\hline \multirow[t]{2}{*}{$\%$ pop. black } & 0.00499 & $0.0116 * * *$ & $0.0127 * * *$ & 0.00532 & -0.000413 & 0.00237 \\
\hline & $(0.00424)$ & $(0.00298)$ & $(0.00340)$ & $(0.00358)$ & $(0.00344)$ & $(0.00287)$ \\
\hline \multirow[t]{2}{*}{$\%$ pop. hispanic } & $0.0199 * * *$ & $0.0237 * * *$ & $0.0222 * * *$ & $0.0223 * * *$ & $0.0190 * * *$ & $0.0138 * * *$ \\
\hline & $(0.00266)$ & $(0.00271)$ & $(0.00197)$ & $(0.00148)$ & $(0.00171)$ & $(0.00203)$ \\
\hline \multirow[t]{2}{*}{ \% pop. 15 to 29} & $0.0716^{* * * *}$ & $0.0811 * * *$ & $0.0764 * * *$ & $0.0789 * * *$ & $0.0660 * * *$ & $0.0570 * * *$ \\
\hline & $(0.0124)$ & $(0.0119)$ & $(0.0125)$ & $(0.0113)$ & $(0.0107)$ & $(0.0134)$ \\
\hline \multirow[t]{2}{*}{$\%$ pop. 30 to 44} & $0.0609 * * *$ & $0.0634 * * *$ & $0.0759 * * *$ & $0.0771 * * *$ & $0.0660 * * *$ & $0.0623 * * *$ \\
\hline & $(0.0199)$ & $(0.0206)$ & $(0.0216)$ & $(0.0181)$ & $(0.0180)$ & $(0.0192)$ \\
\hline \multirow[t]{2}{*}{$\%$ pop. 45 to 59} & $0.112 * * *$ & $0.142 * * *$ & $0.114 * * *$ & $0.114 * * *$ & $0.105^{* * *}$ & $0.0884 * * *$ \\
\hline & $(0.0197)$ & $(0.0213)$ & $(0.0154)$ & $(0.0132)$ & $(0.0138)$ & $(0.0149)$ \\
\hline \multirow[t]{2}{*}{$\%$ pop. 60 or more } & $0.0725 * * *$ & $0.0753 * * *$ & $0.0816 * * *$ & $0.0879 * * *$ & $0.0708 * * *$ & $0.0597 * * *$ \\
\hline & $(0.0115)$ & $(0.0121)$ & $(0.0109)$ & $(0.00957)$ & $(0.00855)$ & $(0.0103)$ \\
\hline \multirow[t]{2}{*}{$\%$ vote for Trump } & $-0.0107 * * *$ & $-0.00882^{* * * *}$ & $-0.00853 * * *$ & $-0.00973 * * *$ & $-0.0108 * * *$ & $-0.0147 * * *$ \\
\hline & $(0.00304)$ & $(0.00256)$ & $(0.00197)$ & $(0.00153)$ & $(0.00167)$ & $(0.00197)$ \\
\hline \multirow[t]{2}{*}{ metro } & $0.479 * * *$ & $0.586^{* * * *}$ & $0.605^{* * *}$ & $0.492 * * *$ & $0.416^{* * *}$ & $0.290 * * *$ \\
\hline & $(0.0810)$ & $(0.0681)$ & $(0.0554)$ & $(0.0500)$ & $(0.0478)$ & $(0.0586)$ \\
\hline \multirow[t]{2}{*}{ non-metro adj } & $0.288 * * *$ & $0.308^{* * * *}$ & $0.344 * * *$ & $0.295 * * *$ & $0.275^{* * *}$ & $0.204 * * *$ \\
\hline & $(0.0649)$ & $(0.0625)$ & $(0.0496)$ & $(0.0449)$ & $(0.0416)$ & $(0.0539)$ \\
\hline \multirow[t]{2}{*}{ unemployment } & $0.0186^{* * *}$ & $0.0278 * * *$ & $0.0247 * * *$ & $0.0156 * * *$ & $0.00767 *$ & 0.00402 \\
\hline & $(0.00707)$ & $(0.00551)$ & $(0.00488)$ & $(0.00424)$ & $(0.00402)$ & $(0.00562)$ \\
\hline \multirow[t]{2}{*}{ income } & $0.00822 * *$ & $0.00974 * * *$ & $0.00793 * * *$ & $0.00707 * * *$ & $0.00759 * * *$ & $0.00697 * *$ \\
\hline & $(0.00341)$ & $(0.00318)$ & $(0.00228)$ & $(0.00229)$ & $(0.00238)$ & $(0.00285)$ \\
\hline \multirow[t]{2}{*}{$\%$ pop. male } & -0.0142 & $-0.0351^{* * * *}$ & $-0.0317 * *$ & -0.0175 & -0.00275 & 0.00160 \\
\hline & $(0.0127)$ & $(0.0128)$ & $(0.0132)$ & $(0.0114)$ & $(0.0114)$ & $(0.0100)$ \\
\hline \multirow[t]{2}{*}{$\%$ pop. white } & -0.00530 & 0.000500 & 0.00251 & -0.00535 & $-0.00994 * * *$ & -0.00396 \\
\hline & $(0.00396)$ & $(0.00312)$ & $(0.00327)$ & $(0.00340)$ & $(0.00322)$ & $(0.00265)$ \\
\hline \multirow[t]{2}{*}{$\%$ pop. black } & 0.00499 & $0.0116 * * *$ & $0.0127 * * *$ & 0.00532 & -0.000413 & 0.00237 \\
\hline & $(0.00424)$ & $(0.00298)$ & $(0.00340)$ & $(0.00358)$ & $(0.00344)$ & $(0.00287)$ \\
\hline \multirow[t]{2}{*}{$\%$ pop. hispanic } & $0.0199^{* * * *}$ & $0.0237 * * *$ & $0.0222 * * *$ & $0.0223 * * *$ & $0.0190 * * *$ & $0.0138 * * *$ \\
\hline & $(0.00266)$ & $(0.00271)$ & $(0.00197)$ & $(0.00148)$ & $(0.00171)$ & $(0.00203)$ \\
\hline
\end{tabular}


Table 2 (continued)

\begin{tabular}{|c|c|c|c|c|c|c|}
\hline Variables & $\begin{array}{l}\text { (1) } \\
\text { OLS }\end{array}$ & $\begin{array}{l}(2) \\
\text { q10 }\end{array}$ & $\begin{array}{l}(3) \\
\mathrm{q} 25\end{array}$ & $\begin{array}{l}(4) \\
q 50\end{array}$ & $\begin{array}{l}(5) \\
q 75\end{array}$ & $\begin{array}{l}(6) \\
q 90\end{array}$ \\
\hline \% pop. 15 to 29 & $\begin{array}{l}0.0716^{* * * *} \\
(0.0124)\end{array}$ & $\begin{array}{l}0.0811^{* * * *} \\
(0.0119)\end{array}$ & $\begin{array}{l}0.0764 * * * \\
(0.0125)\end{array}$ & $\begin{array}{l}0.0789 * * * \\
(0.0113)\end{array}$ & $\begin{array}{l}0.0660 * * * \\
(0.0107)\end{array}$ & $\begin{array}{l}0.0570 * * * \\
(0.0134)\end{array}$ \\
\hline \% pop. 30 to 44 & $\begin{array}{l}0.0609 * * * \\
(0.0199)\end{array}$ & $\begin{array}{l}0.0634 * * * \\
(0.0206)\end{array}$ & $\begin{array}{l}0.0759 * * * \\
(0.0216)\end{array}$ & $\begin{array}{l}0.0771^{* * * *} \\
(0.0181)\end{array}$ & $\begin{array}{l}0.0660 * * * \\
(0.0180)\end{array}$ & $\begin{array}{l}0.0623 * * * \\
(0.0192)\end{array}$ \\
\hline$\%$ pop. 45 to 59 & $\begin{array}{l}0.112 * * * \\
(0.0197)\end{array}$ & $\begin{array}{l}0.142 * * * \\
(0.0213)\end{array}$ & $\begin{array}{l}0.114 * * * \\
(0.0154)\end{array}$ & $\begin{array}{l}0.114 * * * \\
(0.0132)\end{array}$ & $\begin{array}{l}0.105^{* * *} \\
(0.0138)\end{array}$ & $\begin{array}{l}0.0884 * * * \\
(0.0149)\end{array}$ \\
\hline$\%$ pop. 60 or more & $\begin{array}{l}0.0725^{* * *} \\
(0.0115)\end{array}$ & $\begin{array}{l}0.0753^{* * * *} \\
(0.0121)\end{array}$ & $\begin{array}{l}0.0816^{* * * *} \\
(0.0109)\end{array}$ & $\begin{array}{l}0.0879 * * * \\
(0.00957)\end{array}$ & $\begin{array}{l}0.0708 * * * \\
(0.00855)\end{array}$ & $\begin{array}{l}0.0597 * * * \\
(0.0103)\end{array}$ \\
\hline case fatality ratio & $\begin{array}{l}0.538 \\
(0.374)\end{array}$ & $\begin{array}{l}0.393 \\
(0.361)\end{array}$ & $\begin{array}{l}0.431 \\
(0.417)\end{array}$ & $\begin{array}{l}0.745 * * \\
(0.322)\end{array}$ & $\begin{array}{l}0.473^{*} \\
(0.282)\end{array}$ & $\begin{array}{l}0.953 * * \\
(0.455)\end{array}$ \\
\hline cardio hospitalizations & $\begin{array}{l}0.00152 \\
(0.00173)\end{array}$ & $\begin{array}{l}0.00214 \\
(0.00160)\end{array}$ & $\begin{array}{l}0.00282 * * \\
(0.00132)\end{array}$ & $\begin{array}{l}0.00303^{* *} \\
(0.00123)\end{array}$ & $\begin{array}{l}-0.000205 \\
(0.00156)\end{array}$ & $\begin{array}{l}-0.00138 \\
(0.00150)\end{array}$ \\
\hline$\%$ diabetes & $\begin{array}{l}0.0106^{* * *} \\
(0.00500)\end{array}$ & $\begin{array}{l}0.0115 \\
(0.00778)\end{array}$ & $\begin{array}{l}0.0146 * * \\
(0.00609)\end{array}$ & $\begin{array}{l}0.0117 * * \\
(0.00526)\end{array}$ & $\begin{array}{l}0.00928^{*} \\
(0.00563)\end{array}$ & $\begin{array}{l}0.00778 \\
(0.00623)\end{array}$ \\
\hline$\%$ obese & $\begin{array}{l}-0.00175 \\
(0.00520)\end{array}$ & $\begin{array}{l}0.00518 \\
(0.00521)\end{array}$ & $\begin{array}{l}-0.00469 \\
(0.00459)\end{array}$ & $\begin{array}{l}-0.00267 \\
(0.00353)\end{array}$ & $\begin{array}{l}-0.00120 \\
(0.00384)\end{array}$ & $\begin{array}{l}-0.00231 \\
(0.00455)\end{array}$ \\
\hline $\begin{array}{l}\text { \% less than high } \\
\text { school }\end{array}$ & $\begin{array}{l}0.00436 \\
(0.00916)\end{array}$ & $\begin{array}{l}0.00679 \\
(0.00830)\end{array}$ & $\begin{array}{l}0.00800 \\
(0.00583)\end{array}$ & $\begin{array}{l}0.000458 \\
(0.00520)\end{array}$ & $\begin{array}{l}-0.00172 \\
(0.00520)\end{array}$ & $\begin{array}{l}0.00759 \\
(0.00808)\end{array}$ \\
\hline$\%$ some college & $\begin{array}{l}-0.00308 \\
(0.00899)\end{array}$ & $\begin{array}{l}0.000406 \\
(0.00500)\end{array}$ & $\begin{array}{l}0.00125 \\
(0.00535)\end{array}$ & $\begin{array}{l}-0.00121 \\
(0.00422)\end{array}$ & $\begin{array}{l}-0.00626 \\
(0.00416)\end{array}$ & $\begin{array}{l}-0.00720 \\
(0.00592)\end{array}$ \\
\hline$\%$ Bachelors or more & $\begin{array}{l}0.0136 * * \\
(0.00533)\end{array}$ & $\begin{array}{l}0.0180 * * * \\
(0.00640)\end{array}$ & $\begin{array}{l}0.0198 * * * \\
(0.00492)\end{array}$ & $\begin{array}{l}0.0160 * * * \\
(0.00368)\end{array}$ & $\begin{array}{l}0.0100 * * \\
(0.00401)\end{array}$ & $\begin{array}{l}0.00570 \\
(0.00434)\end{array}$ \\
\hline mask law & $\begin{array}{l}0.642 * * * \\
(0.0998)\end{array}$ & $\begin{array}{l}0.632 * * * \\
(0.0484)\end{array}$ & $\begin{array}{l}0.613^{* * *} \\
(0.0408)\end{array}$ & $\begin{array}{l}0.613 * * * \\
(0.0284)\end{array}$ & $\begin{array}{l}0.640 * * * \\
(0.0325)\end{array}$ & $\begin{array}{l}0.651 * * * \\
(0.0398)\end{array}$ \\
\hline Constant & $\begin{array}{l}-6.490 * * * \\
(0.961)\end{array}$ & $\begin{array}{l}-8.518^{* * * *} \\
(1.077)\end{array}$ & $\begin{array}{l}-7.977^{* * * *} \\
(0.893)\end{array}$ & $\begin{array}{l}-7.292 * * * \\
(0.760)\end{array}$ & $\begin{array}{l}-5.454^{* * *} \\
(0.847)\end{array}$ & $\begin{array}{l}-4.478^{* * *} \\
(0.950)\end{array}$ \\
\hline Observations & 2,969 & 2,969 & 2,969 & 2,969 & 2,969 & 2,969 \\
\hline R-sq / Pseudo R-sq & 0.619 & 0.390 & 0.402 & 0.411 & 0.404 & 0.360 \\
\hline
\end{tabular}

$* * * p<0.01 ; * * p<0.05 ; * p<0.1$. Robust standard errors clustered at the state level in parentheses for regression (1).

Bootstrapped standard errors (2000 replications) in parentheses for regressions (2)-(6).

that a one-percentage point increase in this measure leads to about a 0.011 standard deviation increase in mask-wearing behavior.

Out of all the educational attainment variables only the percentage of county population with a Bachelor's degree or higher is statistically significant. The estimated coefficient predicts a 0.014 standard deviation increase in mask wearing behavior for a one-percentage point increase in this measure. The finding may due to the concept of 'exponential growth bias.' Exponential growth bias refers to the difficulty some individuals have in predicting the value of something that grows exponentially as opposed to simple linear growth. If it is the case that those with greater education are better able to understand the increasing danger of COVID-19's exponential 
growth, they may be more inclined to wear a mask in comparison with those with less education. ${ }^{24}$

The variable mask law has a positive estimated coefficient and is significant at better than the one percent level. States that enacted a mask-wearing law prior to the Dynata survey have a sizeable increase in the mask index of about 0.642 standard deviations. This result supports the hypothesis that state mask laws are effective policies for increasing mask-wearing behavior. ${ }^{25,26}$

Finally, we have the variable \% vote for Trump. The estimated coefficient is negative as expected and is statistically significant at better than the one percent level. The results suggest that a one-percentage point increase in a county's vote for Trump in 2016 is associated with a 0.011 standard deviation decrease in maskwearing behavior. This result is consistent with the hypothesis that the President's reluctance to wear a mask while in public is reflected in the mask-wearing behavior of his supporters.

\section{Quantile Regressions}

As was noted earlier, Fig. 3 suggests the presence of heteroscedasticity. This is, in fact, confirmed with a post-estimation test of Eq. (2). ${ }^{27}$ As such, robust standard errors that are clustered at the state level are reported in Table 2, column (1). Another approach is to explore the conditional distribution of the dependent variable using quantile regression. Specifically, quantile regression allows one to consider the impact of various independent variables at different points on the conditional distribution of the dependent variable, mask index. Results for the 10th, 25th, 50th, 75th and 90th quantile estimates are reported in Table 2 in columns (2) through (6), respectively. The results are too numerous to discuss all the estimated coefficients. As is evident for the key independent variable \% vote for Trump, all the estimated coefficients are statistically significant at less than the one percent level and all the signs are negative. Regarding the absolute size of the estimated coefficients, the magnitude dips a little between q10 and q25 and then steadily increases from q25 to q90. The estimated impact of a one-percentage point increase in \% vote for Trump ranges from -0.009 ( $(\mathrm{q} 25)$ to -0.015 (q90) standard deviations. A test of the equivalence of the q10 and q90 estimated coefficients for \% vote for Trump is rejected at nearly the five percent level ( $p$ value $=0.058)$. This suggests that the impact of this measure is significantly larger (in absolute terms) for those in the $90^{\text {th }}$ percentile of the conditional distribution of the dependent variable.

\footnotetext{
24 "Coronavirus is growing exponentially-here's what that really means," The Conversation, updated November 11, 2020. Accessed online at: https://theconversation.com/coronavirus-is-growing-exponentia lly-heres-what-that-really-means-134591.

25 Painter and Qiu (2020) also find significant effects of state policies for social distancing requirements.

${ }^{26}$ Of course, differences in mask laws and their enforcement would likely produce differential impacts of such mandates.

27 A Breusch-Pagan/Cook-Weisberg test for heteroscedasticity produced a chi-squared statistic of 70.07 with a $p$ value of 0.000 .
} 
Turning to the case fatality ratio, this measure has a no significant impact on the dependent variable for lower levels of the conditional distribution (q10 and q25), but is positive and significant for higher levels (q50 through q90). Regarding cardio hospitalizations, this measure emerges with a positive and significant coefficient for the $\mathrm{q} 25$ and q50 regressions. The variable \% diabetes remains positive and significant in the q25, q50 and q75 regressions. Lastly, the estimated coefficients for mask law are all statistically significant, positive and similar in size across all quantiles.

\section{Robustness Checks}

In order to consider the resiliency of the empirical results reported above five robustness checks are explored, the results appear in Table 3. The first robustness check shown in column (1) re-estimates the OLS regression, but now includes population weights. ${ }^{28}$ The R-squared is noticeably larger than that of the OLS value shown in Table 2 . The estimated coefficient for the key independent variable, \% vote for Trump, is slightly smaller, but retains its sign and significance. Other noticeable changes include the loss of significance for unemployment, income, \% pop. 30 to 44 , and \% diabetes. Regarding mask law, the estimated coefficient is significant, positive and slightly smaller than it was in the OLS regression without population weights.

Column (2) adds state fixed effects to the OLS model. ${ }^{29}$ The coefficient for $\%$ vote for Trump is slightly larger (in absolute terms) than the OLS case. One other noticeable difference is that \% obese is now positive and significant at the ten percent level. This suggests that the greater presence of this risk factor increased maskwearing behavior, albeit only slightly.

The regression in column (3) presents the results when census division dummies are included in place of state fixed effects. ${ }^{30}$ This specification allows of the coefficient to mask law to, once again, be estimated. The coefficient to \% vote for Trump is slightly smaller in magnitude than the OLS case. Other noticeable changes include the loss of significance of \% pop. 30 to 44 and \% diabetes. The coefficient to mask law is positive and significant, but noticeably smaller in comparison with the OLS results in Table 2.

The fourth robustness check has to do with the variable mask law. It seems possible that there could be bi-directional causality between this measure and the dependent variable, mask index. That is, while states with mask laws in place may witness greater mask-wearing behavior, it may also be true that mask-wearing behavior may affect the likelihood of a mask law being put into place. ${ }^{31}$ The common solution would be to use an instrumental variables (IV) approach. The challenge here, (as

\footnotetext{
28 The weights are derived from county population values for those 20 years an older.

29 Including state fixed effects prevents the estimation of the coefficient mask law.

30 The estimated coefficients to the census division dummies are excluded for the sake of brevity.

31 The sign of the bi-directional relationship, however, would seem to be in opposite directions. That is, the presence of a mask law would tend to increase mask-wearing behavior, but in states with high usage of facemasks to begin with, the probability of a law being put in place would seem lower as there would be less need for such a law.
} 
Table 3: Robustness checks (dependent variable: standardized mask index $x_{i}$ )

\begin{tabular}{|c|c|c|c|c|c|}
\hline Variables & $\begin{array}{l}\text { (1) } \\
\text { Pop. Weights }\end{array}$ & $\begin{array}{l}(2) \\
\text { State FE }\end{array}$ & $\begin{array}{l}\text { (3) } \\
\text { Divisions }\end{array}$ & $\begin{array}{l}(4) \\
\text { IV }\end{array}$ & $\begin{array}{l}\text { (5) } \\
\text { w/Cases }\end{array}$ \\
\hline$\%$ vote for Trump & $\begin{array}{l}-0.00978 * * * \\
(0.00279)\end{array}$ & $\begin{array}{l}-0.0176^{* * * *} \\
(0.00248)\end{array}$ & $\begin{array}{l}-0.0137 * * * \\
(0.00274)\end{array}$ & $\begin{array}{l}-0.00968 * * \\
(0.00410)\end{array}$ & $\begin{array}{l}-0.0108 * * * \\
(0.00327)\end{array}$ \\
\hline metro & $\begin{array}{l}0.606^{* * * *} \\
(0.0981)\end{array}$ & $\begin{array}{l}0.402 * * * \\
(0.0696)\end{array}$ & $\begin{array}{l}0.414 * * * \\
(0.0760)\end{array}$ & $\begin{array}{l}0.471 * * * \\
(0.0783)\end{array}$ & $\begin{array}{l}0.480 * * * \\
(0.0813)\end{array}$ \\
\hline non-metro adj & $\begin{array}{l}0.300 * * * \\
(0.0832)\end{array}$ & $\begin{array}{l}0.220 * * * \\
(0.0590)\end{array}$ & $\begin{array}{l}0.241 * * * \\
(0.0642)\end{array}$ & $\begin{array}{l}0.277 * * * \\
(0.0675)\end{array}$ & $\begin{array}{l}0.294 * * * \\
(0.0639)\end{array}$ \\
\hline unemployment & $\begin{array}{l}-0.000625 \\
(0.00760)\end{array}$ & $\begin{array}{l}0.0104 * \\
(0.00563)\end{array}$ & $\begin{array}{l}0.00922 \\
(0.00728)\end{array}$ & $\begin{array}{l}0.0265 * * * \\
(0.00960)\end{array}$ & $\begin{array}{l}0.0207 * * * \\
(0.00712)\end{array}$ \\
\hline income & $\begin{array}{l}0.000960 \\
(0.00271)\end{array}$ & $\begin{array}{l}0.00640 * * \\
(0.00271)\end{array}$ & $\begin{array}{l}0.00684 * * \\
(0.00292)\end{array}$ & $\begin{array}{l}0.0105 * * * \\
(0.00340)\end{array}$ & $\begin{array}{l}0.00923 * * \\
(0.00381)\end{array}$ \\
\hline$\%$ pop. male & $\begin{array}{l}0.0140 \\
(0.0168)\end{array}$ & $\begin{array}{l}0.0143 \\
(0.00890)\end{array}$ & $\begin{array}{l}0.00735 \\
(0.0122)\end{array}$ & $\begin{array}{l}-0.0174 \\
(0.0143)\end{array}$ & $\begin{array}{l}-0.0163 \\
(0.0125)\end{array}$ \\
\hline$\%$ pop. white & $\begin{array}{l}-0.00171 \\
(0.00433)\end{array}$ & $\begin{array}{l}-0.000682 \\
(0.00471)\end{array}$ & $\begin{array}{l}-0.000682 \\
(0.00483)\end{array}$ & $\begin{array}{l}-0.00550 \\
(0.00461)\end{array}$ & $\begin{array}{l}-0.00501 \\
(0.00427)\end{array}$ \\
\hline$\%$ pop. black & $\begin{array}{l}0.00470 \\
(0.00476)\end{array}$ & $\begin{array}{l}-0.00187 \\
(0.00415)\end{array}$ & $\begin{array}{l}0.00464 \\
(0.00470)\end{array}$ & $\begin{array}{l}0.00440 \\
(0.00454)\end{array}$ & $\begin{array}{l}0.00539 \\
(0.00432)\end{array}$ \\
\hline$\%$ pop. hispanic & $\begin{array}{l}0.0210 * * * \\
(0.00220)\end{array}$ & $\begin{array}{l}0.00765 * * * \\
(0.00223)\end{array}$ & $\begin{array}{l}0.0169 * * * \\
(0.00244)\end{array}$ & $\begin{array}{l}0.0228 * * * \\
(0.00379)\end{array}$ & $\begin{array}{l}0.0201 * * * \\
(0.00263)\end{array}$ \\
\hline \% pop. 15 to 29 & $\begin{array}{l}0.0331 * * * \\
(0.0118)\end{array}$ & $\begin{array}{l}0.0162 \\
(0.0104)\end{array}$ & $\begin{array}{l}0.0360 * * * \\
(0.0121)\end{array}$ & $\begin{array}{l}0.0850 * * * \\
(0.0192)\end{array}$ & $\begin{array}{l}0.0731 * * * \\
(0.0129)\end{array}$ \\
\hline$\%$ рор. 30 to 44 & $\begin{array}{l}0.0106 \\
(0.0165)\end{array}$ & $\begin{array}{l}0.00772 \\
(0.0147)\end{array}$ & $\begin{array}{l}0.0218 \\
(0.0177)\end{array}$ & $\begin{array}{l}0.0723 * * * \\
(0.0243)\end{array}$ & $\begin{array}{l}0.0618^{* * *} \\
(0.0205)\end{array}$ \\
\hline$\%$ pop. 45 to 59 & $\begin{array}{l}0.0625 * * * \\
(0.0196)\end{array}$ & $\begin{array}{l}0.0366^{* * *} \\
(0.0123)\end{array}$ & $\begin{array}{l}0.0622 * * * \\
(0.0177)\end{array}$ & $\begin{array}{l}0.122 * * * \\
(0.0242)\end{array}$ & $\begin{array}{l}0.111^{* * *} \\
(0.0198)\end{array}$ \\
\hline$\%$ pop. 60 or more & $\begin{array}{l}0.0443 * * * \\
(0.00977)\end{array}$ & $\begin{array}{l}0.0271 * * * \\
(0.0100)\end{array}$ & $\begin{array}{l}0.0439 * * * \\
(0.0109)\end{array}$ & $\begin{array}{l}0.0862 * * * \\
(0.0173)\end{array}$ & $\begin{array}{l}0.0728 * * * \\
(0.0117)\end{array}$ \\
\hline case fatality ratio & $\begin{array}{l}0.631 \\
(0.570)\end{array}$ & $\begin{array}{l}0.265 \\
(0.248)\end{array}$ & $\begin{array}{l}0.390 \\
(0.319)\end{array}$ & $\begin{array}{l}0.566 \\
(0.390)\end{array}$ & \\
\hline cases per 1000 population & & & & 0.000732 & $(0.00350)$ \\
\hline cardio hospitalizations & $\begin{array}{l}0.00312 \\
(0.00203)\end{array}$ & $\begin{array}{l}2.33 e-05 \\
(0.00113)\end{array}$ & $\begin{array}{l}0.000758 \\
(0.00140)\end{array}$ & $\begin{array}{l}0.00330 \\
(0.00211)\end{array}$ & $\begin{array}{l}0.00223 \\
(0.00181)\end{array}$ \\
\hline$\%$ diabetes & $\begin{array}{l}0.00819 \\
(0.00806)\end{array}$ & $\begin{array}{l}0.00376 \\
(0.00503)\end{array}$ & $\begin{array}{l}0.00783 \\
(0.00507)\end{array}$ & $\begin{array}{l}0.00875 * \\
(0.00519)\end{array}$ & $\begin{array}{l}0.0111 * * \\
(0.00504)\end{array}$ \\
\hline$\%$ obese & $\begin{array}{l}-0.00694 \\
(0.00604)\end{array}$ & $\begin{array}{l}0.00519^{*} \\
(0.00288)\end{array}$ & $\begin{array}{l}0.00267 \\
(0.00353)\end{array}$ & $\begin{array}{l}-0.000333 \\
(0.00479)\end{array}$ & $\begin{array}{l}-0.00325 \\
(0.00542)\end{array}$ \\
\hline$\%$ less than high school & $\begin{array}{l}-0.0199 \\
(0.0133)\end{array}$ & $\begin{array}{l}-0.000815 \\
(0.00641)\end{array}$ & $\begin{array}{l}0.00111 \\
(0.00706)\end{array}$ & $\begin{array}{l}0.00969 \\
(0.0118)\end{array}$ & $\begin{array}{l}0.00344 \\
(0.00904)\end{array}$ \\
\hline$\%$ some college & $\begin{array}{l}0.00628 \\
(0.0117)\end{array}$ & $\begin{array}{l}0.00150 \\
(0.00555)\end{array}$ & $\begin{array}{l}0.00752 \\
(0.00691)\end{array}$ & $\begin{array}{l}-0.000175 \\
(0.0101)\end{array}$ & $\begin{array}{l}-0.00349 \\
(0.00898)\end{array}$ \\
\hline
\end{tabular}


Table 3: (continued)

\begin{tabular}{llllll}
\hline Variables & $(1)$ & $(2)$ & $(3)$ & $(4)$ & $(5)$ \\
& Pop. Weights & State FE & Divisions & IV & w/Cases \\
\hline \% Bachelors or more & $0.0144^{*}$ & $0.0113^{* * *}$ & $0.0148^{* * *}$ & $0.0157 * *$ & $0.0119 * *$ \\
& $(0.00723)$ & $(0.00412)$ & $(0.00413)$ & $(0.00595)$ & $(0.00558)$ \\
mask law & $0.562^{* * *}$ & & $0.491 * * *$ & 0.355 & $0.635^{* * *}$ \\
& $(0.0878)$ & & $(0.0644)$ & $(0.238)$ & $(0.106)$ \\
Constant & $-4.173^{* * *}$ & $-2.651^{* * *}$ & $-4.846^{* * *}$ & $-7.806^{* * *}$ & $-6.440^{* * *}$ \\
& $(1.473)$ & $(0.761)$ & $(0.984)$ & $(1.551)$ & $(1.013)$ \\
Observations & 2,969 & 2,969 & 2,969 & 2,969 & 3,076 \\
$R^{2} /$ Pseudo $R^{2}$ & 0.708 & 0.717 & 0.661 & 0.603 & 0.620 \\
\hline
\end{tabular}

Robust standard errors clustered at the state level in parentheses

${ }^{* * *} p<0.01 ; * * p<0.05 ; * p<0.1$

it is in most cases with IV) is to find a suitable set of instruments that clearly meet the necessary conditions to carry out the IV estimation. With no obvious choices for instruments, an alternative is to employ Lewbel's (2012) method of generating instruments from existing data when traditional instruments may not be available. ${ }^{32}$ Results using Lewbel's (2012) methodology appear in Table 3, column (4). ${ }^{33}$ As can be seen, the results in column (4) look quite similar to those in column (1) of Table 2, with one exception. The coefficient to mask law is no longer statistically significant, $(p$-value $=0.142)$. These results, however, must be taken with some caution as the tests for the legitimacy of the generated instruments are not without question. $^{34}$

The final robustness check replaces the case fatality rate with the number of COVID-19 cases per one thousand population. The results shown in column (5) are only marginally different than those found in the OLS results. ${ }^{35}$

\footnotetext{
${ }^{32}$ Lewbel (2016) also shows how his method is also appropriate when the endogenous regressor (mask law in this case) is a binary variable.

33 The results were produced using Stata's ivreg2h routine.

34 The Kleibergen-Paap rk LM statistic test for underidentification easily rejects the null hypothesis. However, the tests for weak instruments (using the Kleibergen-Paap Wald rk F statistic) and overidentification (using the Hansen $\mathrm{J}$ statistic) perform poorly.

35 Another measure equal to the number deaths per one thousand population was explored. The estimated coefficient to this measure was statistically insignificant. The estimated coefficient to the remaining variables in the model was essentially unchanged.
} 


\section{Conclusion}

Chemers (2001, p. 376) describes leadership as, "a process of social influence through which an individual enlists and mobilizes the aid of others in the attainment of a collective goal." Theoretical and experimental studies by economists have found that 'leading by example' is one of the most effective ways of achieving a collective goal. ${ }^{36}$ Clearly, in the midst of a pandemic such as COVID-19, a public health practice of mask wearing (and social distancing) to reduce infection rates would qualify as a 'collective goal.'

The empirical results of this paper provide strong evidence that, after controlling for a variety of other factors, the practice of mask wearing is significantly less in counties where then-candidate Donald Trump received strong support in the 2016 presidential election. This result is consistent with the theory that Trump supporters are looking to the president for guidance on the importance of wearing a mask to battle COVID-19 and the message they are getting is that masks are not important. This message may prove to be very costly in terms of economic losses, illnesses, and deaths. $^{37}$

Of course, to definitively claim that the results in this paper show that President Trump's reluctance to wear a mask has caused his supporters to also not wear a mask would require a counterfactual. ${ }^{38}$ For example, we could ask, "What would've happened if Trump had strongly supported mask wearing?" Given the uniqueness of the event and the disposition of the president, this counterfactual will not be forthcoming. Nevertheless, the analysis provided in this paper hopefully illustrates the need to decrease the partisan influences on health policy and replaces it with guidance from science.

Funding No funding was for conducting this study.

Availability of data and materials Data available upon request from the author.

Code availability Stata code available upon request from the author.

\section{Compliance with ethical standards}

Conflict of interest The author declares no conflicts or competing interests.

\footnotetext{
36 Regarding theoretical work, Hermalin (1998) is an important reference. As for experimental studies, see: Potters et al. (2007), Gächter et al. (2012) and Dannenberg (2015).

37 Mask-wearing behavior of state governors could also influence mask-wearing behavior of individuals in their state. This could be a topic of further research.

38 The reluctance of some individuals to wear masks could be driven more generally by 'anti-science' beliefs. In this case, if Donald Trump also displays a general mistrust of science, then the correlation between mask-wearing behavior and voting for Trump may be due to this mutual mistrust of science rather than Trump's reluctance to wear a mask specifically. (Thanks are due to an anonymous referee for this point.)
} 


\section{Appendix 1: Data Sources}

\section{Dependent Variable}

Estimates from The New York Times, based on roughly 250,000 interviews conducted by Dynata from July 2 to July 14. Available at: https://github.com/nytimes/ covid-19-data/tree/master/mask-use.

\section{Independent Variables}

Voting data: Dave Leip's Atlas of U.S. Elections, available at: https://uselectionatlas .org/.

Population demographics: U.S. Census Bureau, American Community Survey, https://www.census.gov/programs-surveys/acs/data/summary-file.html.

Unemployment data: Bureau of Labor Statistics, Local Area Unemployment Statistics (LAUS), https://www.bls.gov/lau/.

Income and Rural-Urban Continuum Codes: U.S. Census Bureau, Model-based Small Area Income \& Poverty Estimates, https://www.census.gov/programs-surve ys/saipe.html.

Risk factors data related to COVID-19: Centers for Disease Control and Prevention, https://nccd.cdc.gov/DHDSPAtlas/?state=County.

Corona virus data (cases and deaths by county): Centers for Disease Control and Prevention, https://covid.cdc.gov/covid-data-tracker/?CDC_AA_refVa $\mathrm{l}=\mathrm{https} \% 3 \mathrm{~A} \% 2 \mathrm{~F} \% 2 \mathrm{Fwww} . c d c . g o v \% 2 \mathrm{Fcoronavirus} \% 2 \mathrm{~F} 2019$-ncov $\% 2 \mathrm{Fcases}-$ updat es $\% 2$ Fcounty-map.html\#county-map.

Mask laws: CNN, "These are the states requiring people to wear masks when out in public," https://www.cnn.com/2020/06/19/us/states-face-mask-coronavirus-trnd/ index.html. Accessed on August 10, 2020.

\section{Appendix 2: Description of Survey Methodology}

The following is a description of how the survey data produced by Dynata were compiled. This is a quote from the source of the data:

To transform raw survey responses into county-level estimates, the survey data was weighted by age and gender, and survey respondents' locations were approximated from their ZIP codes. Then estimates of mask-wearing were made for each census tract by taking a weighted average of the 200 nearest responses, with closer responses getting more weight in the average. These tract-level estimates were then rolled up to the county level according to each tract's total population.

(Source: https://github.com/nytimes/covid-19-data/blob/master/mask-use/ README.md). 


\section{References}

Allcott, Hunt, Levi Boxell, Jacob Conway, Matthew Gentzkow, Michael Thaler, and David Y. Yang. 2020. Polarization and Public Health: Partisan Differences in Social Distancing during the Coronavirus Pandemic. Forthcoming in Journal of Public Economics. https://ssrn.com/abstract=3570274

Barro, Robert J., José F. Ursúa and Joanna Weng. 2020. The Coronavirus and the Great Influenza Pandemic: Lessons from the "Spanish Flu for the Coronavirus' Potential Effects on Mortality and Economic Activity. NBER Working Paper \# 26866. http://www.nber.org/papers/w26866.

Bordalo, Pedro, Marco Tabellini and David Y. Yang. 2020. Stereotypes and Politics. NBER Working Paper \# 27194. https://www.nber.org/papers/w27194

Boxell, Levi, Matthew Gentzkow and Jesse M. Shapiro. 2020. Cross-Country Trends in Affective Polarization. NBER Working Paper \# 26669.at: http://www.nber.org/papers/w26669.

Chemers, Martin M. 2001. Leadership Effectiveness: An Integrative Review. In Blackwell Handbook of Social Psychology Group Processes, ed. Michael A. Hogg and Scott Tindale376-399. Oxford: Blackwell.

Chetty, Raj, John N. Friedman, Nathaniel Hendren, Michael Stepner, and the Opportunity Insights Team. 2020. How Did COVID-19 and Stabilization Policies Affect Spending and Employment? A New Real-Time Economic Tracker Based on Private Sector Data. Opportunity Insights, Working Paper. https://opportunityinsights.org/paper/tracker/.

Clinton, Joshua, Jon Cohen, John S. Lapinski and Marc Trussler. 2020. Partisan Pandemic: How Partisanship and Public Health Concerns Affect Individuals' Social Distancing During COVID-19. https:// ssrn.com/abstract=3633934.

Dannenberg, Astrid. 2015. Leading by Example Versus Leading by Words in Voluntary Contribution Experiments. Social Choice and Welfare 44: 71-85

Dolan, Brian. 2020. Unmasking History: Who Was Behind the Anti-Mask League Protests During the 1918 Influenza Epidemic in San Francisco? Perspectives in Medical Humanities (UC Medical Humanities Consortium. https://doi.org/10.34947/M7QP4M.

Frost, Wade H. 1920. Statistics of Influenza Morbidity: with Special Reference to Certain Factors in Case Incidence and Case Fatality. Public Health Reports 35(11): 584-597

Gächter, Simon, Danielle Nosenzo, Elke Renner, and Martin Sefton. 2012. Who Makes a Good Leader? Cooperativeness, Optimism, and Leading-by-Example. Economic Inquiry 50(4): 956-967

Goldstein, Joshua A. and Ronald D. Lee. 2020. Demographic Perspectives on Mortality of COVID-19 and Other Epidemics. NBER Working Paper \# 27043. http://www.nber.org/papers/w27043.

Hauser, Christine. 2020. The Mask Slackers of 1918. New York Times, accessed on August 20, 2020 at: https://www.nytimes.com/2020/08/03/us/mask-protests-1918.html.

Hermalin, Benjamin E. 1998. Toward an Economic Theory of Leadership: Leading by Example. American Economic Review 88(5): 1188-1206

King, Maryon F., and Gordon C. Bruner. 2000. Social Desirability Bias: A Neglected Aspect of Validity Testing. Psychology and Marketing 17(2): 79-103

Lewbel, Arthur. 2012. Using Heteroscedasticity to Identify and Estimate Mismeasured and Endogenous Regressor Models. Journal of Business and Economic Statistics 30: 67-80

Lewbel, Arthur. 2016. Identification and Estimation Using Heteroscedasticity Without Instruments: The Binary Endogenous Regressor Case. Boston College Economics Working Paper 927. http://fmwww .bc.edu/EC-P/wp927.pdf.

MacIntyre, C. Raina., and Abrar A. Chughtai. 2020. A Rapid Systematic Review of the Efficacy of Face Masks and Respirators Against Coronaviruses and Other Respiratory Transmissible Viruses for the Community, Healthcare Workers and Sick Patients. International Journal of Nursing Studies 108: 103629

Painter, Marcus and Tian Qiu. 2020. Political Beliefs affect Compliance with COVID-19 Social Distancing Orders. https://ssrn.com/abstract=3569098.

Pew Research Center. 2017. The Partisan Divide on Political Values Grows Even Wider. https://www. pewresearch.org/politics/2017/10/05/the-partisan-divide-on-political-values-grows-even-wider/.

Potters, Jan, Martin Sefton, and Lise Vesterlund. 2007. Leading-by-Example and Signaling in Voluntary Contribution Games: An Experimental Study. Economic Theory 33: 169-182

Purtle, Jonathan, Neal D. Goldstein, Eli Edson, and Annamarie Hand. 2017. Who Votes for Public Health? U.S. Senator Characteristics Associated with Voting in Concordance with Public Health Policy Recommendations (1998-2013). SSM - Population Health 3: 136-140 
Zhang, Renyi, Yixin Li, Annie L. Zhang, Yuan Wang, and Mario J. Molina. 2020. Identifying Airborne Transmission as the Dominant Route for the Spread of COVID-19. Proceedings of the National Academy of Sciences 117(26): 14857-14863

Publisher's Note Springer Nature remains neutral with regard to jurisdictional claims in published maps and institutional affiliations. 